\title{
Education for a Traditional Medicine in Medical Schools in Japan
}

\author{
Ye-Seul Myeong ${ }^{1 *}$, Soo-Yeon Ahn ${ }^{1 *}$, Chang-Gue Son ${ }^{2}$ \\ ${ }^{1}$ College of Oriental Medicine, Daejeon University, \\ ${ }^{2}$ Liver and Immunology Research Center of Daejeon University Oriental Hospital
}

\section{일본 의과대학에서의 전통의학 교육의 현황 조사연구}

\author{
명예슬 ${ }^{1 *} \cdot$ 안수연 $^{1 \star} \cdot$ 손창규 $^{2}$ \\ ${ }^{1}$ 대전대학교 한의과대학, ${ }^{2}$ 대전대학교 대전한방병원 간-면역연구센터
}

\begin{abstract}
Objectives : This study aimed to overview the current education status of a traditional medicine by medical schools in Japan. Methods : We surveyed the literatures regarding a traditional medicine education in Japan, and get the information via email-interview with an officer of medical schools in Japan as well as from their websites. Results : Japan's education ministry presented the appropriateness of education for traditional medicine to medical students in 2001, and most of medical schools begun to set up the classes in Japan. We received the detail information of the traditional medicine education from 21 medical schools. Nineteen colleges (approximately 90\%) of those have the regular classes for traditional medicine while two colleges don't have the education program for the traditional medicine. Most of medical schools have single class for introduction of traditional medicine, and have average $16.2 \pm 8.8$ hours during the $4^{\text {th }}$ grade $(61.9 \%)$. Conclusions : We presented the general feature of education for traditional medicine in Japan, and this result would be basic information for an establishment of a strategy regarding the enhancement of national competitiveness of traditional Korean medicine.
\end{abstract}

Key words : traditional medicine, integrative medicine, kampo medicine, globalization

\section{Introduction}

There are increasing interests in traditional medicine worldwide due to the currently intensive attention for quality of life and limitations of conventional medicine against chronic diseases ${ }^{1)}$. A various types of traditional medicines including Oriental medicine are called as a complementary and alternative medicine(CAM). A report from 'Global Industry Analysts, Inc.' presented that the world market size of CAM industry will grow from 89.8 billion in 2011year 114.1 billion dollars, as a $6.0 \%$ of grow rate annually ${ }^{2}$.

According to these environmental changes of CAM market, medical schools in Korean and other countries started to teach the subjects related to CAM including traditional medicines ${ }^{3,4}$. The convention medical community now calls integrative medicine, the combined form of western medicine and traditional medicine. Korean education association of integrative medicine now takes the necessary of education of

Received December 9, 2015, Revised February 7, 2016, Accepted February 22, 2016

Corresponding author: Chang-Gue Son

Liver and Immunology Research Center, Daejeon Oriental Hospital of Daejeon University, 176-9 Daeheung-ro, Jung-gu, Daejeon 34929, Korea

Tel: +82-42-229-6723, Fax:+82-42-257-6398, E-mail: ckson@dju.ac.kr

*These authors contributed equally to this work.

(c) This is an open access article distributed under the terms of the Creative Commons Attribution Non-Commercial License (http://creativecommons.org/licenses/ by-nc/4.0) which permits unrestricted non-commercial use, distribution, and reproduction in any medium, provided the original work is properly cited. 
CAM in medical schools in Korea for granted, and proposed a standardized curriculum of the integrative medicine for CAM education ${ }^{5}$. A graduate school for CAM was established in Cha medical school in $2000^{6}$, and a department of integrative medicine was opened in a Catholic medical school in 2004 ${ }^{7}$. About 30 of total 41 medical schools in Korea have started to teach the lectures for CAM by $2010^{8}$.

On the other hand, Japan and Korea has a geological and cultural similarity in term of a traditional medicine, called as Kampo medicine, from Chinese medicine, while a Japan has a different license system for medical doctor". After a medical license for Oriental doctor was repealed in 1874, a traditional medicine has been practiced by doctors learned western medicine in Japan. Accordingly the general level of the Japanese traditional medicine and its public service is known to be lower than China or Korea ${ }^{10}$. Japan however has directed their efforts to the development of Kampo medicine recently such as making a board system for Kampo medicine specialist since 1989 and including 149 of herbal medicines in a list of public insurance-covering drug ${ }^{11)}$. In addition, Japan has an approximately 20\% of world market for CAM, and shows a competitiveness in manufacturing herbal products and its market ${ }^{12)}$.

In order to produce essential information for preparation against rapid changes of the integrative medicine-derived environment, this study aimed to review the education of traditional medicine in medical schools in Japan which tried early to combine the Western medicine and Oriental medicine.

\section{Methods}

\section{Study design}

This study surveyed the current status of education of traditional medicine in medical schools in Japan regarding the subjects and hours of classes.

\section{Data collection and analysis}

Literature survey was conducted using electronic database of Japan statics(http://www.e-stat.go.jp/), KISS(http://kiss. kstudy.com/), and PubMed(http://www.ncbi.nlm.nih.gov/ pubmed) from their inception to February 28, 2015. Search terms comprised combinations of the following keywords: "Japan", "traditional medicine”, "Oriental medicine", "Kampo medicine", "complementary and alternative medicine" and "education". Various related reports were searched form homepages of the government-related organizations including Japan's education ministry(www.mext.go.jp/), Japan's Ministry of Health(http://www.mhlw.go.jp/), Japan Society for Oriental Medicine(www.jsom.or.jp), and Korean institute of Oriental Medicine(www.kiom.re.kr). In addition, and we get the information from websites of medical schools in Japan and via email-interview with their officer in case of unclear.

\section{Results}

\section{Brief history of traditional medicine in Japan}

The ancient Japan received medical knowledge firstly from Korea, and then directly imported the Chinese medicine after Jichong(知聰) took various medical text books for herbs, formulae and acupuncture from Oh-kingdom(吳) to Japan in 562 $2^{13)}$. An ancient doctor, Tasirosanki(田大三喜, 1465 1544) advocated the theory of eight principle pattern(八綱辩登) by receiving Chinese medicine of Geum-Won era(金元時代), and

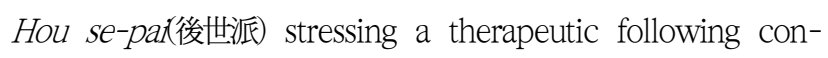
firming symptom(察證辨治) begun by Manasedosan(曲直瀨道 三, 1507 1594) ${ }^{14}$. From 18 century, several typical groups focusing their medical theories had been developed, likely $G u$ bang-pax古方派), Zhe zhong-pax折衰派), and Gu zheng-pai

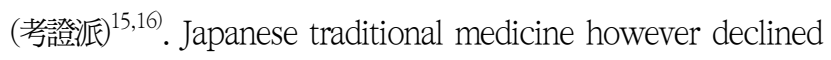
rapidly after the abandonment of Oriental medicine via reform plan for medical system in 1874(Fig. 1).

\section{Brief history for education of traditional medicine in Japan}

Japanese traditional medicine declined after the abandonment of Oriental medicine by government in 1874 . Some doctors individually have succeeded the traditional medicine, and Japan Society for Oriental medicine was established by 


$\begin{array}{cc}\text { Ancient } & \begin{array}{c}\text { Middle ages } \\ \text { BC3500 AD 1185 }\end{array} \\ \text { Imported Chinese medicine of } \\ \text { Invited ancient } & \text { Geum-Won Era (金元時代), and } \\ \text { Korean doctors } & \text { presented theory of eight } \\ \text { principle pattern (八綱辨證) }\end{array}$

Imported Chinese medical

books by Jichong (知聰) of

Oh kingdom (吳)

\section{Appearance of}

"Hou se-pai (後世派)"

Fig. 1. Summary for history of traditional medicine in Japan.

- Medical college educating Kampo medicine

--- University hospital having Kampo clinic

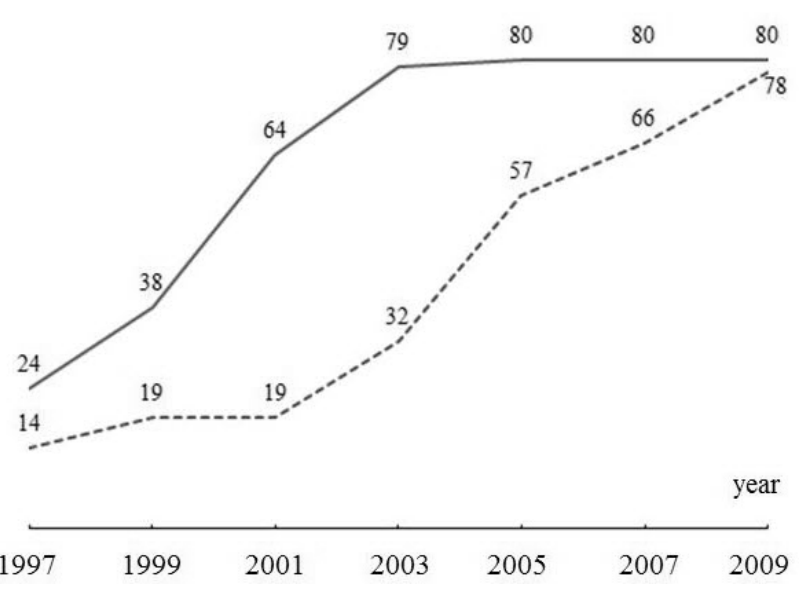

Fig. 2. Number of medical schools educating Kampo medicine.

mainly young doctors in 1950, which regularized the study of the traditional medicine in Japan. The board for Oriental medicine specialist was started since 1989, and the research and education for traditional medicine was conducted by these specialists in Japan $^{8}$. From the mid-1990s, several medical schools begun to open the classes for traditional medicine in Japan. Japan's education ministry presented the appropriateness of education for traditional medicine to medical students in 20017). Toyama University, a national medical school having class of traditional medicine, developed an education plan, called "Model Core Curriculum", and

\section{Modern times}

$\sim 1912$

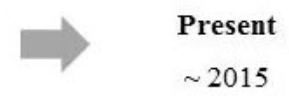

$\sim 2015$

Hound Japan Society tor

Oriental Medicine in 1950

"Gu bang-pai (古方派)",

"Zhe zhong-pai (折叓派)"

followed by "Gu zheng-pai (考

證派)"

Reform plan for medical system in 1874
Began Oriental specialist in1989

Announcing "model core curriculum" by Japan's education ministry in 2001

a survey study in 2009 that most of medical schools prepared the education of traditional medicine since 2004(Fig. 2) ${ }^{18)}$.

\section{Analysis of Kampo medicine education in medical schools in Japan}

The total number of medical school is 80, as 42 belonged in national University, 8 in public University and 30 in private University respectively. Ten medical schools presented the information for education of traditional medicine in their online website, while others didn't show the information. We had sent email to an officer of other medical schools(58 schools) for asking the detail information, and then 11 schools gave us responses. Among above 21 medical schools, Miyazaki University and Gunma University didn't have the class for traditional medicine currently, and others have the education classes. Four medical schools of Kitasato, Toho, Kochi, and Toyama University have 2 subjects, while the rest have only one subject, introduction of Oriental medicine, Kampo medicine, or integrative medicine. The average duration of education $16.2 \pm 8.8$ hours, and $61.9 \%$ of schools educate students on $4^{\text {th }}$ grade(Table 1 ).

\section{Discussion and Conclusion}

Japan traditional medicine had declined due the aban- 
Table 1. Completion Status of Kampo Medicine Subjects in Medical School, Japan

\begin{tabular}{|c|c|c|c|}
\hline Name of university & Name of subjects & Hours & Grade \\
\hline Aichi Medical Univ.(http://www.aichi-med-u.ac.jp/) & Oriental medicine & 16 & 4 \\
\hline Dokkyo Medical Univ.(http://www.dokkyomed.ac.jp/) & Oriental medicine & 9 & 4 \\
\hline Fujita Health univ.(http://www.fujita-hu.ac.jp/) & Oriental medicine & 24 & 3 \\
\hline Hirosaki Univ.(http://www.med.hirosaki-u.ac.jp) & Clinical pharmacology and Kampo medicine & 24 & 4 \\
\hline Hyogo College Of Medicine(http://www.hyo-med.ac.jp/) & Introduction to traditional medicine & 12 & 3 \\
\hline Juntendo Univ.(http://www.juntendo.ac.jp/) & Integrated clinical medicine & 6 & 4 \\
\hline Keio Univ.(http://www.keio.ac.jp/index-jp.html) & Kampo medicine & 12 & 4 \\
\hline Kitasato Univ.(http://www.kitasato-u.ac.jp/) & $\begin{array}{l}\text { Oriental medicine } \\
\text { General medical care }\end{array}$ & $\begin{array}{l}12 \\
24\end{array}$ & $\begin{array}{l}3 \\
6\end{array}$ \\
\hline Kochi Medical Univ.(http://www.kochi-ms.ac.jp/) & $\begin{array}{l}\text { Alternative medicine } \\
\text { Medical communication }\end{array}$ & $\begin{array}{l}30 \\
30\end{array}$ & $\begin{array}{l}3 \\
4\end{array}$ \\
\hline Kyorin Univ.(http://www.kyorin-u.ac.jp/) & Introduction to Kampo medicine & 18 & 4 \\
\hline Nagasaki Univ.(http://www.med.nagasaki-u.ac.jp/) & Clinical core lecture & 6 & 5 \\
\hline Nagoya City Univ.(http://www.nagoya-cu.ac.jp/1.htm) & Semminar for Kampo medicine & 12 & 4 \\
\hline Osaka City Univ.(http://www.osaka-cu.ac.jp/ja) & Introduction to Kampo medicine & 12 & $2,3,4$ \\
\hline Shinshu Univ.(http://www.shinshu-u.ac.jp/) & Oriental medicine & 29 & 3 \\
\hline Toho Univ.(http://www.toho-u.ac.jp/) & $\begin{array}{l}\text { Oriental medicine(basis) } \\
\text { Oriental medicine(clinical) }\end{array}$ & $\begin{array}{l}10 \\
15\end{array}$ & $\begin{array}{l}2 \\
4\end{array}$ \\
\hline Tottori Univ.(http://www.med.tottori-u.ac.jp/) & Topics in clinical medicine 2 & 7 & 6 \\
\hline Toyama Univ.(http://www.med.u-toyama.ac.jp) & $\begin{array}{l}\text { Introduction to Kampo medicine } \\
\text { Kampo medicine care }\end{array}$ & $\begin{array}{l}34 \\
15\end{array}$ & $\begin{array}{l}2 \\
4\end{array}$ \\
\hline Wakayama Medical Univ.(http://www.wakayama-med.ac.jp/) & Kampo medicine & 13 & 4 \\
\hline Yokohama City Univ.(http://www.yokohama-cu.ac.jp/) & Clinical pharmacology and Oriental medicine & 3 & 4 \\
\hline
\end{tabular}

donment of Oriental medicine in 1874; however the increase of concern about CAM worldwide leaded the preparation of new education plan by Japan's education ministry, a core curricula learning traditional medicine in all medical schools in $2001^{17)}$. Since then, among the 80 medical schools, a rapidly increasing number of them have integrated traditional medicine, called as Kampo medicine, into their curricula ${ }^{19)}$, and most University hospital had opened Kampo clinic by 2009 ${ }^{18)}$.

We had surveyed the current status of education for traditional medicine in Japanese medical schools by February 28, 2015. Beside 10 medical schools presenting the information for education of traditional medicine in their website, we received the detail information via email from other medical schools. A recent report presented that Kampo medicine has been taught at all 80 medical schools and universities since $2007^{20}$. Another study reported that 98\% of the medical schools have the at least one education class for traditional medicine in 2012 21 . In our study, however two schools, Miyazaki University and Gunma University, don't have any class for traditional medicine currently. Therefore it is supposed that several medical schools had stopped the Kampo education program after 2009 year.

From our survey, only four medical schools of have 2 subjects, while the rest have only one subject. The name of subjects involved the introduction of Oriental medicine, Kampo medicine, traditional medicine, and integrative medicine. Another study reported that the subjects included mainly the basis of traditional Japanese Kampo medicine by $81 \%$ of the schools, and Chinese medicine by $19 \%$, and Western alternative medicine by $20 \%{ }^{21)}$. The average duration of Kampo medicine education $16.2 \pm 8.8$ hours. This means that most medical schools are teaching the general concept of traditional medicine during one semester. Any Japanese licensed physician can prescribe Kampo drug, moreover it was known that $70 \%$ to $97 \%$ of Japanese physicians prescribe Kampo medicine ${ }^{22}$. Japanese medical schools however only offer students traditional medicine education for an extremely limited amount of time. Even though the medical system is different, Chinese medical schools for western medicinal doctors provide around 80 hour class of traditional Chinese medicine ${ }^{23)}$. 
On the other hand, Japan has a board system for Kampo medicine specialist since 1989. After they achieved doctor license, they have to pass the examination with reporting their 50 clinical cases of the experienced Kampo medicine. Over 2,000 of Kampo medicine specialist has been licensed by $2015^{24)}$. Above fact would indicate that the practical education of traditional medicine in Japan has been conducted after graduation of medical school. Regarding the Kampo medicine education, the greatly limited class, un-standardized curriculum, and the small number of well-trained full-time instructors are blamed for the hindrance of the improvement of Kampo education ${ }^{19)}$. Many Japanese doctors however practice frequently traditional medicine utilizing simple handbooks from the perspective of modern Western medicine. This might be due to the development of especially Kampo extract formulations and extensive scientific evidence for the Kampo formulae ${ }^{25,26}$.

This study has limitation of restricted data because Japanese literatures might be missed and the number of medical schools with full information was small. Nevertheless this study helped us to understand the current status of Japanese traditional medicine education and their trial for development of Japanese traditional medicine. These results would be basic information for an establishment of a strategy regarding the enhancement of national competitiveness of traditional Korean medicine.

\section{Acknowledgement}

This study was supported by the Oriental Medicine Research and Development Project, Ministry of Health and Welfare(HI15C-0112-000015), South Korea.

\section{References}

1. Korean Medical Association. The Trend of CAM Study in USA: Yesterday and Today. Symposium. 2010.

2. Report from Global Industry Analysts, Inc. Alternative
Medicine: A Global Outlook. Global Industry Analysts. 2012.

3. Consortium of Academic Health Centers for Integrative Medicine. Curriculum in integrative medicine: a guide for medical educators. Available at: http://www.imconsortium.org

4. Gaster B, Unterborn JN, Scott RB, Schneeweiss R. What should learn about complementary and alternative medicine. Acad Med $2007 ; 82: 934-938$

5. Hyoung Kyu Kim. For standardization of the integrativemedicine curriculum. Korean J. medical education. 2008 ; $20: 95-97$.

6. Cha medical school. Available at: http://gam.cha.ac.kr/ college/college_main.aspx

7. Available at: http://medicine.catholic.ac.kr/html/about/class_ main.jsp?nav_class_code=CC001\& nav_major_code=BMC013

8. Chang BH. Complementary and Alternative Medicine(CAM) Education and Medical Students' Attitudes toward CAM. Hanyang medical reviews. 2010 ; 30(2) : 136-141.

9. Ryu GC, Lee HW, Oh SJ, Park CJ. International competitiveness and tasks of Korean traditional medicine from the perspective of international comparison of curricula and research. Korean Institute for Health and Social Affairs. 2005 ; 25(2) : 107-146.

10. Shin HK, Lim BM. Research institutes on traditional medicine in East Asia countries and USA. Korean J. Oriental Med. 2002 ; 8(2) : $67-74$.

11. Choi BR, Jo YJ, Son CG. Study on the State of Kampo Medical Services in Japan. J. Int. Korean Med. 2014 ; 35(3) : 309-316.

12. Shin HK. A study on the current status and prospect of CAM world market. Institute of Korean Traditional Medicine. 2007 ; 226-228.

13. Kim KW, Park HK. The study of 'Hou se-pai' . J. Korean Medical Classics. 2006 ; 19(3) : 198-199.

14. A therapeutic following confirming symptom

15. Kim KW, Park HK. The study of 'Zhe zhong-pai'. J. Korean Medical Classics 2007 ; 20(3) : 121-141.

16. Kim KW, Park HK. The study of 'Kao Zheng Pai'. J. Korean Medical Classics. 2007 ; 20(4) : 211-250.

17. Joe KH. Japanese Kampo medicine. Seoul. Gunja publisher. 2008.

18. Institute of Korean traditional medicine. Report: Current status of Kampo medicine education and Kampo medicine specialist. 
2009.

19. Motoo Y, Seki T, Tsutani K.Traditional Japanese medicine, Kampo: its history and current status. Chin J. Integ. Med. $2011 ; 17(2): 85-87$.

20. Imau Y, Kim SJ, Odaguchi H, Yanagisawa H, Sakiyama T. The current Kampo education at 80 University faculties of medicine. Kampo. Med. 2012 ; 63 (2) : 121-130.

21. Arai M, Katai S, Muramatsu S, Namiki T, Hanawa T, Izumi S. Current status of Kampo medicine curricula in all Japanese medical schools. BMC Complement Altern Med. 2012 ; 12(207) : 207.

22. Oka T: The role of Kampo(Japanese traditional herbal) medi- cine in psychosomatic medicine practice in Japan. International Congress Series 2006 ; 1287 : 304-308.

23. Gao P, Munakata K, Zhan R, Imazu Y, Matsuura K, Aiso S, Watanabe K. Comparison traditional medicine educational systems in Japan and China. Kampo med. 2012 ; 2 : 131-137.

24. Japan Society for Oriental medicine. Available from: http:// www.jsom.or.jp/index.html

25. Nishimura K, Plotnikoff GA, Watanabe K. Kampo medicine as an integrative medicine in Japan. JMAJ. $2009 ; 52: 147-149$.

26. Motoo Y, Arai I, Hyodo I, Tsutani K: Current status of Kampo (Japanese herbal) medicines in Japanese clinical practice guidelines. Complement Ther Med. 2009 ; 17(3) : 147-154.

\section{국문초록}

목적 : 본 연구는 일본 의과대학에서의 전통의학의 교육 현황에 대한 개괄적 정보를 생성하기 위함이다. 방법 : 연구자들은 그 동안의 발표된 논문을 비롯한 일본 의과대학에서 웹사이트에 공지된 내용 및 각 의과대학의 행정부서와의 전자메일을 통해서 취득한 정보를 통하여 전통의 학 교육에 대한 분석을 하였다. 결과 : 2001 년 일본 문부성이 의과대학생의 전통의학에 대한 교육의 당위성을 고지한 이후에, 대부분의 일본 의 의과대학에서는 전통의학의 과목을 신설하기 시작하였다. 본 연구에서 자세한 정보를 확보한 의과대학의 전통의학 교육에 대한 분석 결과, 약 $90 \%$ 의 일본 의과대학에서 정규과목으로서 전통의학 관련 교육을 실시하고 있었다. 교육내용은 대부분이 전통의학 개론에 대한 것으로, $61.9 \%$ 가 4학년 학생들에게 실시되고 있으며, 평균 강의시간은 $16.2 \pm 8.8$ 시간이었다. 결과 : 본 연구의 결과는 향후 한국한의학의 국제화를 비롯한 대외적 경쟁력 확보 전략의 수립에 중요한 기초자료로 활용되길 기대한다. 